\title{
Korelasi Antara Kadar Total Flavonoid dan Fenolik dari Ekstrak dan Fraksi Daun Jati Putih (Gmelina arborea Roxb.) Terhadap Aktivitas Antioksidan
}

\author{
(Correlation Between Total Phenolic and Flavonoid Contents of Jati Putih (Gmelina \\ arborea Roxb.) Leaves Extract and Fraction Toward Antioxidant Activity)
}

\author{
Syamsu Nur ${ }^{1}$, Fitriyanti Jumaetri Sami², Wilda $\mathbf{R}^{2}$, Akbar Awaluddin², Mutiara Indah Ayu \\ Afsari $^{2}$ \\ ${ }^{1}$ Depertemen Kimia Farmasi, Akademi Farmasi Kebangsaan Makassaar,.Jl. Perintis Kemerdekaan Km 13,7, \\ Daya Makassar \\ ${ }^{2}$ Departemen Kimia Farmasi, Sekolah Tinggi Ilmu Farmasi Makassar, Jl. Perintis Kemerdekaan Km 13,7, Daya \\ Makassar
}

Article Info:

Received: 02 March 2019

in revised form: 16 March 2019

Accepted: 23 March 2019

Available Online: 23 March 2019

Keywords:

Gmelina arborea Roxb

Total phenolic

Total flavonoid

Antioxidants

Corresponding Author:

Syamsu Nur

Akademi Farmasi Kebangsaan

Makassar, Jalan Perintis

Kemerdekaan Km. 13,7 Daya -

Makassar 90242

Indonesia

Email:

syamsunur19@gmail.com

\begin{abstract}
This experiment aims to determine the correlation of total phenolic and flavonoid content of jati putih leaves fraction (Gmelina arborea Roxb.) towards Antioxidant activity. Sample was extracted by maceration method using ethanol $70 \%$ to obtain the ethanol extract (EE), followed by liquidliquid extraction method to obtain fraction of ethyl acetate (EA) and nHexane (EH). The phytochemical screening and determination of total phenolic and flavonoid content were done by colorimetric method. Antioxidant activity were done by DPPH, FRAP and ABTS methods. Phytochemical screening showed positive results for flavonoids, phenolic and saponins. The largest total phenolic content was found on EA (11,59 $\mu \mathrm{g} / \mathrm{ml} \pm 0,3 \% \mathrm{~b} / \mathrm{b}$ EAG) and the largest total flavonoid content was on EA $(3,88 \mu \mathrm{g} / \mathrm{ml} \pm 0,02 \% \mathrm{~b} / \mathrm{b}$ EK). The total phenolic and flavonoid content of Jati putih leaves has a correlation with antioxidant activity. The coefficient correlation of activity on reducingDPPH radical was 56,7\% (total of phenolic content) and 57,8\% (total of flavonoid content) and on iron reduction power in FRAP method was 99,9\% (total of phenolics and flavonoids content). The relationship with the activity in reducing radical ABTS obtained coefficient correlation of $57,0 \%$ and $58,1 \%$ for total phenolic and flavonoids contents, respectively.
\end{abstract}

Copyright (C) 2019 JFG-UNTAD

This open access article is distributed under a Creative Commons Attribution (CC-BY-NC-SA) 4.0 International license.

How to cite (APA 6th Style):

Nur. S., Sami. F. J., Wilda R., Awaluddin A., Afsari. M. I. A., (2019). Korelasi Antara Kadar Total Flavonoid dan Fenolik dari Ekstrak dan Fraksi Daun Jati Putih (Gmelina arborea Roxb.) Terhadap Aktivitas Antioksidan. Jurnal Farmasi Galenika : Galenika Journal of Pharmacy, 5(1), 33-42. doi:10.22487/j24428744.2019.v5.i1.12034 


\begin{abstract}
ABSTRAK
Penelitian ini bertujuan untuk menentukan adanya korelasi antara kadar total flavonoid dan fenolik dari fraksi daun jati putih (Gmelina arborea Roxb.) terhadap aktivitas antioksidan . Proses penyiapan ekstrak dilakukan dengan metode maserasi dengan pelarut etanol 70\% sehingga diperoleh ekstrak etanol 70\% (EE), dilanjutkan dengan proses partisi dengan metode ekstraksi cair-cair sehingga diperoleh fraksi etil asetat (EA), dan fraksi n-Heksan (EH). Uji skrining fitokimia dan penentuan kadar flavonoid dan fenolik total dengan metode kolorimetri. Aktivitas antioksidan menggunakan pengujian DPPH, FRAP dan ABTS. Uji skrining fitokimia diperoleh hasil positif adanya flavonoid, fenolik dan saponin. Dari hasil penelitian diperoleh data kandungan flavonoid total yang terbesar yaitu EA

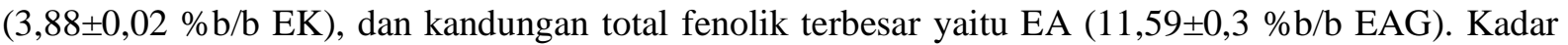
total flavonoid dan fenolik pada daun jati putih menunjukkan adanya hubungan dengan aktivitas antioksidan. Hubungannya dengan aktivitas dalam meredam radikal DPPH diperoleh nilai koefisien korelasi sebesar 0,578\% (kadar total flavonoid) dan 0,567\% (kadar total fenolik) dan hubungan terhadap daya reduksi besi pada metode FRAP sebesar 0.999\% (kadar total flavonoid dan fenolik). Hubungannya dengan aktivitas dalam meredam radikal ABTS diperoleh nilai koefisien korelasi sebesar $0.581 \%$ dan $0.570 \%$ berturut-turut untuk kadar total fenolik dan flavonoid.
\end{abstract}

Kata Kunci : Gmelina arborea Roxb, flavonoid total, fenolik total, Antioksidan.

\section{PENDAHULUAN}

Radikal bebas merupakan molekul yang sangat reaktif karena mempunyai elektron yang tidak berpasangan. Radikal bebas yang berlebih dapat menyerang senyawa apa saja terutama lipid dan protein yang berimplikasi pada timbulnya berbagai penyakit degeneratif (Middleton et al., 2000), karena kurangnya antioksidan dalam tubuh yang tidak mampu mengimbangi terjadinya oksidasi (Kusumowati, 2012) seperti penyakit jantung, arterioskelerosis, kanker serta gejala penuaan (Tahir et al., 2003).

Antioksidan merupakan senyawa atau molekul yang berperan dalam menstabilkan radikal bebas melalui donor elektron dan menghambat terjadinya reaksi berantai dari pembentukan radikal bebas (Lü et al., 2010). Antioksidan eksogen dapat diperoleh dalam bentuk sintetik atau secara alami. Antioksidan buatan seperti asam benzoat, BHA (Butylated Hydroxy Anisol), BHT (Butylated Hydroxy Toluene) atau TBHQ (Tertier Butylated Hydroxy Quinone) dapat menimbulkan efek samping pada kesehatan tubuh. Oleh karena itu, diperlukan senyawa antioksidan alami yang merupakan alternatif untuk digunakan sebagai pengganti antioksidan sintetis. Antioksidan alami dapat diperoleh dari tumbuh-tumbuhan atau buah-buahan yang mengandung senyawa metabolit sekunder berupa flavonoid dan fenolik yang berguna sebagai penangkap radikal bebas (Cos et al., 1998).

Fenolik ataupun flavonoid merupakan metabolit sekunder yang tersebar dalam tumbuhan dimana diketahui sangat berperan terhadap aktivitas antioksidan, semakin besar kandungan senyawa golongan fenol maka semakin besar aktivitas antioksidannya (Konaté et al., 2010, Shahwar et al., 2010). Beberapa penelitian tentang aktivitas antioksidan dari senyawa fenolik mengatakan bahwa strukturnya dapat berkontribusi terhadap aktivitasnya (Apak et al., 2007). Aktivitas struktur dari fenolik bergantung pada jumlah dan lokasi gugus -OH yang berperan dalam menetralkan radikal bebas. Senyawa fenolik telah diketahui memiliki berbagai efek biologis seperti aktivitas antioksidan melalui mekanisme sebagai pereduksi, penangkap radikal bebas, pengkhelat logam, peredam terbentuknya oksigen singlet serta pendonor elektron (Karadeniz et al., 2005).

Jati putih (Gmelina arborea Roxb) merupakan famili dari Verbenaceae yang diketahui memiliki aktivitas sebagai antioksidan. Studi fitokimia yang nyata pada genus Gmelina menunjukkan bahwa berbagai kelas metabolit sekunder diidentifikasi seperti flavonoid, 
fenolat dan iridoid (Adhyapak et al., 2011, Madhan Shankar et al., 2009, Kaur et al., 2012). Kulit batang dari G. arborea dilaporkan mengandung glikosida, tannin, fenolik, saponin, steroid dan terpen yang diperoleh pada ektrak dengan berbagai pelarut (Chothani and Patel, 2012). Selain itu, pada Akar dan daun dari Gmelina arborea telah memiliki aktivitas anti-inflamasi, antimikroba antioksidan, anthelmintik, aktivitas sitotoksik, aktivitas anti-ulkus, efek diuretik, aktivitas anti diabetes, dan kardioprotektif (Vijay et al., 2011). Adanya kandungan flavonoid dan fenolik memberikan banyak manfaat dalam pengembangan obat bahan alam khususnya sebagai antioksidan.

Berdasarkan uraian di atas, maka perlu dilakukan penelitian untuk mengetahui adanya hubungan antara kadar total flavonoid dan fenolik terhadap aktivitas antioksidan yang terdapat pada fraksi dari Gmelina arborea Roxb.

\section{METODE PENELITIAN}

\section{Alat dan Bahan}

Alat-alat yang digunakan yaitu : Bejana maserasi, cawan porselin, kertas saring, mikropipet (Huawei 1000, China), rotary evaporator (IKA ${ }^{\circledR} R V 10$, germany), seperangkat alat-alat gelas (pyrex ${ }^{\circledR}$ ), spektrofotometer UV-VIS $\left(\right.$ Shimadzu $\left.^{\circledR}\right)$, dan timbangan analitik (Mettlet Toledo ${ }^{\circledR}$ ).

Bahan-bahan yang digunakan yaitu : Daun Jati Putih (Gmelina arborea Roxb) diperoleh dari Daya, Sulawesi Selatan, ABTS (Sigma-Aldrich), air suling, aluminium klorida (Merck, Germany), asam galat (Merck, Germany), asam sitrat (Merck, Germany), DPPH (Sigma-Aldrich), ekstrak daun jati putih, etanol p.a (Merck, Germany), etanol 70\%, etil asetat (Merck, Germany), $\mathrm{FeCl}_{3}$ (Sigma-Aldrich), $\mathrm{HCl}$ pekat (Merck, Germany), $\mathrm{K}_{2} \mathrm{~S}_{2} \mathrm{O}_{8}$ (Merck, Germany), Kuarsetin (Sigma-Aldrich), n-Heksan (Merck, Germany), $\mathrm{Na}_{2} \mathrm{CO}_{3}$ 7,5\% (Merck, Germany), natrium klorida (Sigma-Aldrich), serbuk Mg (Sigma-Aldrich), reagen Folin-Ciocalteau (Merck, Germany) dan TPTZ (Sigma-Aldrich).

\section{Penyiapan sampel}

Daun jati putih diambil yang masih segar kemudian dicuci lalu daun jati putih dipotong-potong kasar dan dikeringkan pada lemari pengering. Selanjutnya simplisia yang diperoleh diserbukkan dengan derajat halus yang sesuai. Sebanyak 500 gram serbuk simplisia kering daun jati putih dimasukkan ke dalam bejana maserasi, kemudian ditambahkan etanol $70 \%$ sampai sampel terendam (1:8). Kemudian wadah ditutup dan pengadukan dilakukan sesekali. Proses maserasi dilakukan 3x24 jam. Maserat disaring dan residu diremaserasi dengan pelarut yang sama selama 1x24 jam lalu maserat disaring dan residu diremaserasi kembali dengan perlakuan yang sama selama 1x24 jam. Maserat yang diperoleh dikumpulkan dan dipekatkan dengan menggunakan alat rotary evaporator hingga diperoleh ekstrak kental.

\section{Ekstraksi Cair-Cair}

Ekstrak kental ditimbang \pm 20 gram dan dilarutkan dalam etanol $70 \%$ : air ( 1:2) kemudian diekstraksi cair-cair dengan pelarut n-Heksan $50 \mathrm{ml}$. Lalu fraksi n-Heksan diambil dan dipisahkan. Selanjutnya fraksi etanol : air diekstraksi cair-cair kembali dengan pelarut etil asetat $50 \mathrm{ml}$, lalu masing-masing fraksi etanol : air dan fraksi etil asetat diambil dan dipisahkan. Masing-masing fraksi etil asetat dan nHeksan yang dihasilkan, diuapkan dengan alat rotary evaporator.

\section{Identifikasi Kualitatif pada sampel}

\section{a. Uji Flavonoid}

Ekstrak dan fraksi dilarutkan dengan pelarut etanol 70\%. Setelah itu ditambahkan serbuk Mg dan 0,5 ml $\mathrm{HCl}$ pekat. Warna merah sampai jingga diberikan oleh senyawa flavon, warna merah tua diberikan oleh flavonol dan flavonon (Robinson, 1995).

\section{b. Uji Fenolik}

Uji fenolik dilakukan dengan mengambil ekstrak dan fraksi sebanyak $1 \mathrm{ml}$ direaksikan dengan larutan $\mathrm{FeCl}_{3} 1 \%$, jika terjadi warna biru tua, atau biru kehitaman menunjukkan adanya senyawa fenol (Harborne, 1987).

\section{c. Uji alkaloid}

Sejumlah ekstrak dimasukkan ke dalam tabung reaksi, ditetesi dengan $\mathrm{HCl} 2 \mathrm{~N}$ dipanaskan kemudian didinginkan, lalu dibagi dalam beberapa tabung reaksi. Tiap tabung dengan masing-masing perekasi. Pada penambahan perekasi Mayer, positif mengandung alkaloid jika terbentuk endapan putih. Pada penambahan pereaksi Wagner, positif mengandung alkaloid jika terbentuk endapan coklat. 
Pada penambahan perekasi dragendorf, positif mengandung alkaloid jika terbentuk endapan jingga (Joshi et al., 2013)

\section{d. Uji Saponin}

Sejumlah ekstrak dimasukkan ke dalam tabung reaksi ditambahkan $10 \mathrm{ml}$ air panas, didinginkan dan kemudian dikocok kuat-kuat selama 10 detik. Positif mengandung saponin jika terbentuk busa setinggi 1$10 \mathrm{~cm}$ selama tidak kurang dari 10 menit dan pada penambahan 1 tetes $\mathrm{HCl} 2 \mathrm{~N}$ buih tidak menghilang (Joshi et al., 2013).

\section{Penentuan Kadar Flavonoid}

Penentuan kadar flavonoid total dilakukan berdasarkan metode kolorimetri menggunakan aluminium klorida $\left(\mathrm{AlCl}_{3}\right)$ yang dimodifikasi (Amzad Hossain and Shah, 2015). Masing-masing sampel dan larutan standar (Kuersetin) dipipet sebanyak 0,5 mL dimasukkan ke dalam labu takar $5 \mathrm{~mL}$. Selanjutnya ditambahkan 0,5 ml larutan aluminium klorida $\left(\mathrm{AlCl}_{3}\right.$ $10 \%$ ) dan $0.5 \mathrm{ml}$ natrium asetat selanjutnya dicukupkan dengan metanol. Campuran diinkubasi selama 30 menit. Diukur absorbansinya dengan spektrofotometer UV-Vis pada panjang gelombang $437 \mathrm{~nm}$.

\section{Penentuan Kadar Fenolik Total}

Penentuan kadar fenolik total dilakukan dengan menggunakan metode Folin-Ciocalteau secara kolorimeter yang diadopsi dari (Chun et al., 2003) dengan sedikit modifikasi. Larutan standar (asam galat) dan larutan ekstrak dipipet sebanyak 0,5 ml ke dalam labu takar $5 \mathrm{ml}$ dan ditambahkan $0,5 \mathrm{ml}$ reagen Folin-Ciocalteu, didiamkan selama 3-5 menit. Selanjutnya ditambahkan dengan $2 \mathrm{ml} \mathrm{Na}_{2} \mathrm{CO}_{3} 7,5 \%$ dan dicukupkan volumenya dengan akuades hingga 5 ml. Masing-masing Larutan diinkubasi pada suhu kamar selama 30 menit, kemudian diukur absorbansi sampel pada panjang gelombang maksimum $774 \mathrm{~nm}$.

\section{Penentuan Aktivitas Antioksidan}

Pengujian aktivitas antioksidan dilakukan dengan menggunakan tiga jenis pengujian yang berbeda antara lain: 1,2-diphenyl-2-picrylhydrazyl (DPPH), Ferric Reducing Antioxidant Power (FRAP) dan 2,2'-azino-bis(3-ethylbenzothiazoline-6-sulphonic acid (ABTS) yang diadopsi dari Nur et al., (2017), Benzie and Strain, (1996), Iqbal et al., (2015) dengan sedikit dimodifikasi.

\section{Pengujian antiradikal DPPH}

Disiapkan larutan DPPH 0,4 mM dan dibuat seri konsentrasi sampel ekstrak etanol $20-100 \mu \mathrm{g} / \mathrm{ml}$, fraksi etil asetat $4-20 \mu \mathrm{g} / \mathrm{ml}$, dan fraksi n-heksan $200-600 \mu \mathrm{g} / \mathrm{ml}$. masing-masing seri ditambahkan 1 ml larutan DPPH, dicukupkan volumenya dengan etanol p.a, selanjutnya campuran divorteks dan diinkubasi pada ruang gelap selama 30 menit pada suhu kamar. Kemudian diukur absorbansinya dengan spektrofotometer UV-Vis dengan panjang gelombang $515 \mathrm{~nm}$. Disiapkan juga larutan blanko sebagai kontrol negative. Nilai IC $_{50}$ pada peredaman radikal DPPH diketahui dari grafik regresi linear yang diplot antara konsentrasi sampel terhadap \% penghambatan.

\section{Penentuan Aktivitas Antioksidan Dengan Metode FRAP}

Disiapkan larutan $\mathrm{FeCl}_{3}$ (3 $\mathrm{mM}$ dalam $5 \mathrm{mM}$ asam sitrat) dan TPTZ (1 mM dalam 0,05 M HCl). Dibuat seri konsentrasi ekstrak etanol 70\% (10 - $50 \mu \mathrm{g} / \mathrm{ml})$, fraksi etil asetat (10 - $50 \mu \mathrm{g} / \mathrm{ml})$, dan fraksi n-Heksan (20 - $100 \mu \mathrm{g} / \mathrm{ml}$ ) serta larutan standar asam askorbat. Masing-masing seri ditambahkan 2,5 ml TPTZ, 0,5 $\mathrm{ml} \mathrm{FeCl}_{3}$ dan dicukupkan volumenya dengan etanol p.a. Selanjutnya campuran divorteks dan diinkubasi selama 30 menit pada suhu kamar. Kemudian diukur absorbansinya dengan spektrofotometer UV-Vis pada panjang gelombang $620 \mathrm{~nm}$. Data absorbansi sampel dihitung terhadap regresi linier larutan asam askorbat dan ditetapkan kapasitas antioksidan sebagai Equivalent Ascorbic Acid Antioxidant Capacity (AEAC) yang dinyatakan dalam mg AEAC/g ekstrak.

\section{Penentuan Aktivitas Antioksidan Dengan Metode ABTS}

Disiapkan larutan $\mathrm{ABTS}^{+}$yang dibuat dari campuran 7,4 mM larutan ABTS dan 2,6 mM larutan kalium persulfat dengan perbandingan yang sama (1:1) dan diinkubasi selama 12 jam pada tempat yang gelap. Dibuat seri konsentrasi ekstrak etanol 70\% (5 - 25 $\mu \mathrm{g} / \mathrm{ml})$, fraksi etil asetat $(1-5 \mu \mathrm{g} / \mathrm{ml})$, dan fraksi nHeksan (20-100 $\mu \mathrm{g} / \mathrm{ml})$. Masing-masing seri ditambahkan $1 \mathrm{ml}$ larutan $\mathrm{ABTS}^{+}$dan dicukupkan volumenya dengan etanol p.a. Selanjutnya campuran divorteks dan diinkubasi pada ruang gelap selama 10 menit pada suhu kamar. Kemudian diukur absorbansinya dengan spektrofotometer UV-Vis dengan panjang gelombang $750 \mathrm{~nm}$. Nilai $\mathrm{IC}_{50}$ pada peredaman radikal kation ABTS diketahui berdasarkan persamaan regresi linear yang diperoleh 
dari plot konsentrasi sampel terhadap \% penghambatan.

\section{Analisis Data}

Analisis data dilakukan dengan merepresentasikan data hasil penelitian sebagai mean \pm standar deviasi (SD) menggunakan perangkat Microsoft Excel yang ditentukan dari hasil pengujian masing-masing sampel sebanyak tiga replikasi.

\section{HASIL DAN PEMBAHASAN}

Proses ekstraksi dengan metode maserasi menggunakan pelarut etanol 70\% sehingga diperoleh ekstrak kental berwarna hijau pekat dengan rendamen sebesar $15,67 \%$. Selanjutnya dilakukan proses partisi dengan metode ekstraksi cair-cair sehingga diperoleh fraksi etil asetat kering berwarna hijau muda dengan rendamen sebesar 6,5 \% , dan fraksi n-Heksan kering berwarna kuning muda dengan rendamen sebesar $2,12 \%$.

Penapisan fitokimia dilakukan untuk memperoleh data awal mengenai senyawa metabolit sekunder pada sampel yang dinilai berkhasiat sebagai antioksidan. Senyawa metabolit sekunder yang secara umum telah diketahui bersifat sebagai antioksidan yaitu flavonoid, fenolik, saponin, steroid dan triterpenoid (Kurniasih et al., 2015). Berdasarkan pada uji skrining fitokimia diperoleh hasil positif adanya flavonoid, fenolik dan saponin (Tabel 1).

Tabel 1. Hasil Identifikasi Senyawa Kimia

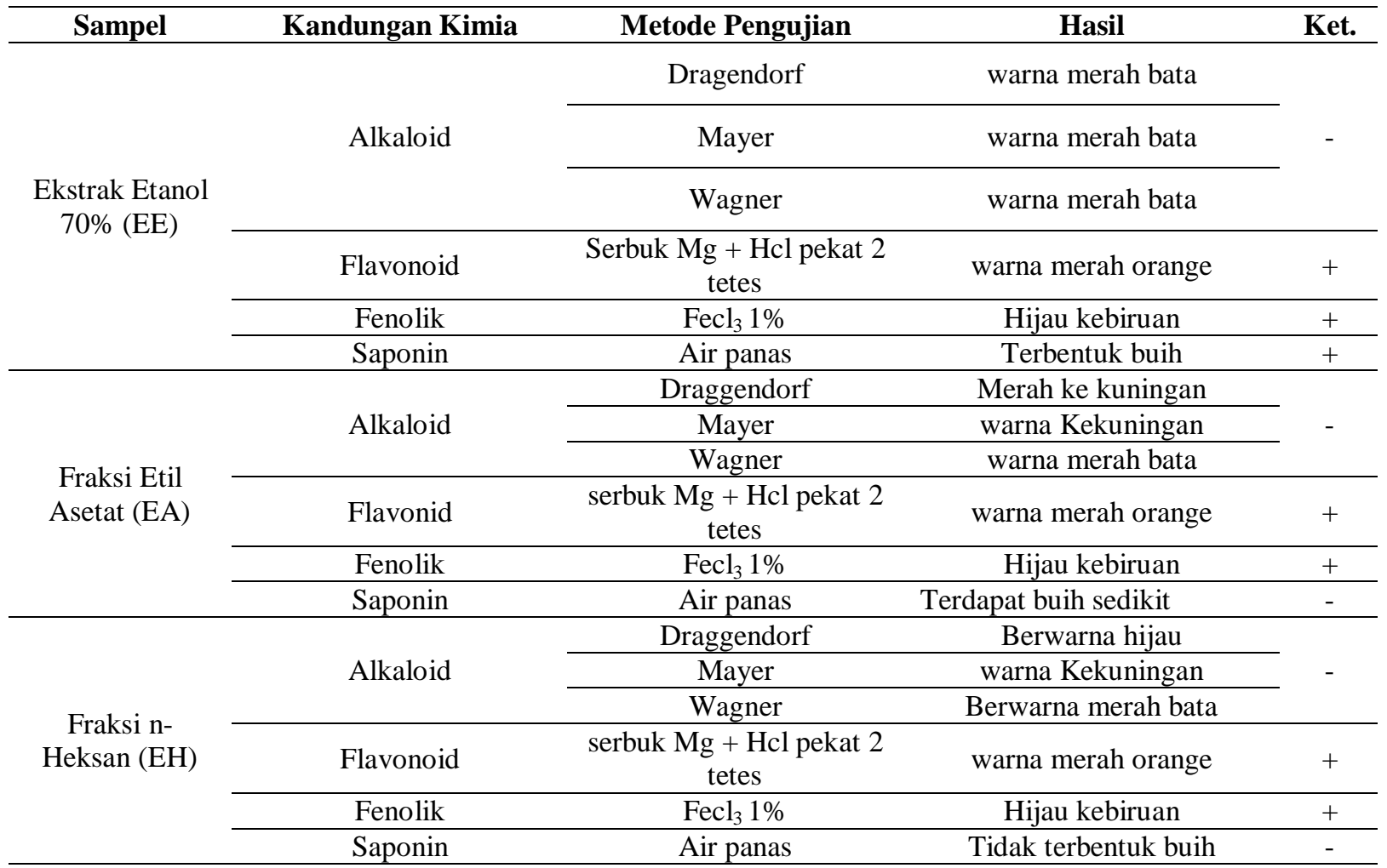

Keterangan : (+) kandungan kimia terdeteksi, (-) kandungan kimia tidak terdeteksi 
Tabel 2. Kadar Total Flavonoid Dan Fenolik serta Aktivitas Antioksidan

\begin{tabular}{|c|c|c|c|c|c|}
\hline \multirow{2}{*}{ Sampel } & \multirow{2}{*}{$\begin{array}{c}\text { Kadar Flavonoid } \\
\text { (\%b/b EK) }\end{array}$} & \multirow{2}{*}{$\begin{array}{c}\text { Kadar Fenolik } \\
\text { (\%b/b EAG) }\end{array}$} & \multicolumn{3}{|c|}{ Aktivitas Antioksidan } \\
\hline & & & DPPPH $(\mu \mathrm{g} / \mathrm{ml})$ & $\begin{array}{c}\text { FRAP (mg AEAC/g } \\
\text { ekstrak) }\end{array}$ & $\begin{array}{l}\text { ABTS } \\
(\mu \mathrm{g} / \mathrm{ml})\end{array}$ \\
\hline EE & $1,72 \pm 0,04 \%$ & $4,25 \pm 0,05 \%$ & $67.77 \pm 0.28$ & $232.14 \pm 5.85$ & 15.77 \\
\hline EA & $3,88 \pm 0,02 \%$ & $11,59 \pm 0,3 \%$ & $14.37 \pm 0.15$ & $539.95 \pm 3.77$ & 2.93 \\
\hline $\mathrm{EH}$ & $0.94 \pm 0,02 \%$ & $1,75 \pm 0,05 \%$ & $606.9 \pm 2.97$ & $110.68 \pm 4.30$ & 113.94 \\
\hline
\end{tabular}

Keterangan : Ekstrak Etanol 70\% (EE), Fraksi Etil Asetat (EA), Fraksi n-Heksan (EH). Data hasil pengukuran diekspresikan sebagai mean $\pm \mathrm{SD}, n=3$.

\section{Penentuan Kadar Total Flavonoid Dan Fenolik}

Penentuan kandungan total flavonoid dan fenolik dari ekstrak etanol $70 \%$ dan masing-masing fraksi ditentukan berdasarkan metode kolorimetri dengan $\mathrm{AlCl}_{3}$ yang direpresentasikan sebagai \%b/b ekivalen kuarsetin (\%b/b EK). Sedangkan penentuan kandungan fenolik total dilakukan menggunakan metode kolorimetri dengan pereaksi follin-ciocalteu dimana hasilnya dilaporkan sebagai \% b/b ekivalen asam galat (\%b/b EAG). Data pada Tabel 2 menunjukkan bahwa fraksi etil asetat mengandung kadar flavonoid yang tertinggi yaitu sebesar $3,88 \pm 0,02 \%$ yang diikuti oleh ekstrak Etanol $70 \%$ sebesar 1,72 $\pm 0,04 \%$ dan fraksi n-Heksan sebesar $0.94 \pm 0,02 \%$. Kadar flavonoid total yang diperoleh juga berkorelasi terhadap kadar fenolik dari sampel, juga diperoleh hasil bahwa fraki etil asetat memberikan kadar fenolik yang tertinggi yaitu $11,59 \pm 0,3 \%$ diikuti ekstrak etanol $70 \%$ (4,25 $\pm 0,05 \%)$ dan Fraksi n-Heksan (1,75 $\pm 0,05 \%)$. Hasil tersebut merupakan data awal untuk dikorelasikan terhadap aktivitas antioksidan dari masing-masing sampel.

\section{Penentuan Aktivitas Antioksidan}

Antioksidan merupakan senyawa pendonor elektron dan memiliki berat molekul kecil, tetapi mampu menginaktivasi berkembangnya reaksi oksidasi, dengan cara mencegah terbentuknya radikal (Lü et al., 2010). Penentuan aktivitas antioksidan dilakukan menggunakan metode peredaman radikal DPPH, dimana metode ini merupakan metode yang sederhana, mudah untuk penapisan aktivitas penangkapan radikal beberapa senyawa, efektif dan praktis (Molyneux, 2003). Pengujian dengan radikal DPPH didasarkan pada reduksi senyawa radikal DPPH yang berwarna ungu menjadi warna kuning oleh karena terjadinya reaksi transfer atom hidrogen oleh senyawa antioksidan sehingga radikal DPPH menjadi stabil (Kulisic et al., 2004, Nur et al., 2017). Hasil yang di peroleh menunjukkan bahwa fraksi etil asetat memberikan penghambatan yang sangat kuat ditandai dengan nilai IC $_{50}$ yang terkecil yaitu 14,37 $\pm 0.15 \mu \mathrm{g} / \mathrm{ml}$, dan ekstrak etanol $70 \%$ dengan nilai $\mathrm{IC}_{50} 66,77 \pm 0.28 \mu \mathrm{g} / \mathrm{ml}$ memberikan penghambatan yang kuat dalam meredam radikal DPPH sedangkan untuk fraksi n-Heksan dengan nilai 606,9 \pm 2.97 $\mu \mathrm{g} / \mathrm{ml}$ memberikan hasil penghambatan yang sangat lemah (Tabel 2).

Pada penelitian ini, juga digunakan metode FRAP berdasarkan pada metode Benzie dan Strain (1996) dengan sedikit modifikasi dimana digunakan $\mathrm{FeCl}_{3}$ dalam larutan asam sitrat sebagai penghasil ion $\mathrm{Fe}^{3+}$ yang terikat kompleks dengan ligan penstabil 2,4,6tripyrydil-s-triazine (TPTZ) membentuk $(\mathrm{Fe}(\mathrm{II})(\mathrm{TPTZ}) 2)^{3+}$. Dalam metode ini kompleks $(\mathrm{Fe}(\mathrm{II})(\mathrm{TPTZ}) 2)^{3+}$ yang tidak berwarna akan direduksi menjadi kompleks (Fe(II)(TPTZ)2) ${ }^{2+}$ yang berwarna biru. Pembentukkan warna biru akan menaikkan absorbansi sampel yang menunjukkan kenaikan daya reduksi. Besarnya daya reduksi suatu sampel menunjukkan kemampuannya sebagai donor elektron dan dapat bereaksi dengan radikal untuk mengubahnya menjadi stabil serta mengakhiri rantai radikal (Apak et al., 2007, Nur et al., 2017). Aktivitas antioksidan berdasarkan pengujian Ferric Reducing Antioxidan Power (FRAP) fraksi etil asetat menunjukkan bahwa fraksi etil asetat memiliki daya reduksi terbesar yaitu 539.95 $\pm 3.77 \mathrm{mg}$ AEAC/g ekstrak, dan diikuti ekstrak etanol $70 \%$ sebesar 232.14 $\pm 5.85 \mathrm{mg} \mathrm{AEAC/g}$ estrak dan fraksi n-Heksan sebesar 110.68 $\pm 4.30 \mathrm{mg}$ AEAC/g ekstrak (Tabel 2). Berdasarkan hasil tersebut terlihat bahwa fraksi etil asetat daun jati putih memiliki aktivitas antioksidan yang kuat dibandingkan dengan ekstrak etanol 70\% dan fraksi n-Heksan dalam mereduksi besi. Semakin besar nilai AEAC sampel maka semakin besar 
aktivitas antioksidannya dalam mereduksi $\mathrm{Fe}^{3+}$ menjadi $\mathrm{Fe}^{2+}$.

Selain menggunakan metode DPPH dan FRAP, pengujian aktivitas antioksidan juga dilakukan dengan menggunakan metode peredaman radikal kation ABTS (2,2 azinobis (3-etilbenzotiazolin)-6asam sulfonat). Metode ini menggunakan prinsip inhibisi yaitu sampel ditambahkan pada sistem penghasil radikal bebas dan pengaruh inhibisi terhadap efek radikal bebas diukur untuk menentukan total kapasitas antioksidan dari sampel (Wang et al., 2004). Hasil yang di peroleh pada panjang gelombang $750 \mathrm{~nm}$ menunjukkan bahwa fraksi etil asetat memberikan penghambatan yang sangat kuat yang ditandai dengan nilai $\mathrm{IC}_{50}$ yang terkecil yaitu 2,93 $\mu \mathrm{g} / \mathrm{ml}$, diikuti ekstrak etanol $70 \%$ dengan nilai IC $_{50} 15.17 \mu \mathrm{g} / \mathrm{ml}$ dan fraksi n-Heksan dengan nilai $133.94 \mu \mathrm{g} / \mathrm{ml}$. (Tabel 2).

Kandungan total flavonoid terhadap aktivitas dalam meredam radikal DPPH memiliki korelasi dengan nilai koefisien korelasi $\left(\mathrm{R}^{2}\right)$ sebesar 0,578 (Gambar 1a) yang berarti $57,8 \%$ kapasitas antioksidan pada masing-masing sampel dipengaruhi oleh kandungan flavonoid dan 42,2\% di pengaruhi oleh senyawa lain. Dan kandungan total fenolik diperoleh nilai koefisien korelasi sebesar 0.567 (Gambar 2a) yang berarti $56,7 \%$ kapasitas antioksidan pada masing-masing sampel dipengaruhi oleh kandungan total fenolik dan 43,3\% dipengaruhi oleh senyawa lain. Berdasarkan pada hasil tersebut menunjukkan bahwa baik fenolik maupun flavonoid memberikan korelasi sedang terhadap aktivitas antiradikal DPPH.

Berbeda dengan aktivitas antioksidan dalam mereduksi besi pada metode FRAP dimana menunjukkan bahwa adanya korelasi yang tinggi antara kandungan total flavonoid dan total fenolik terhadap aktivitas antioksidan dalam mereduksi besi dengan nilai koefisien korelasi $\left(\mathrm{R}^{2}\right)$ sebesar 0,999 (Gambar 1b \& 2b) yang berarti 99.9\% aktivitas antioksidan pada masing-masing sampel dipengaruhi oleh kandungan total flavonoid dan fenolik.

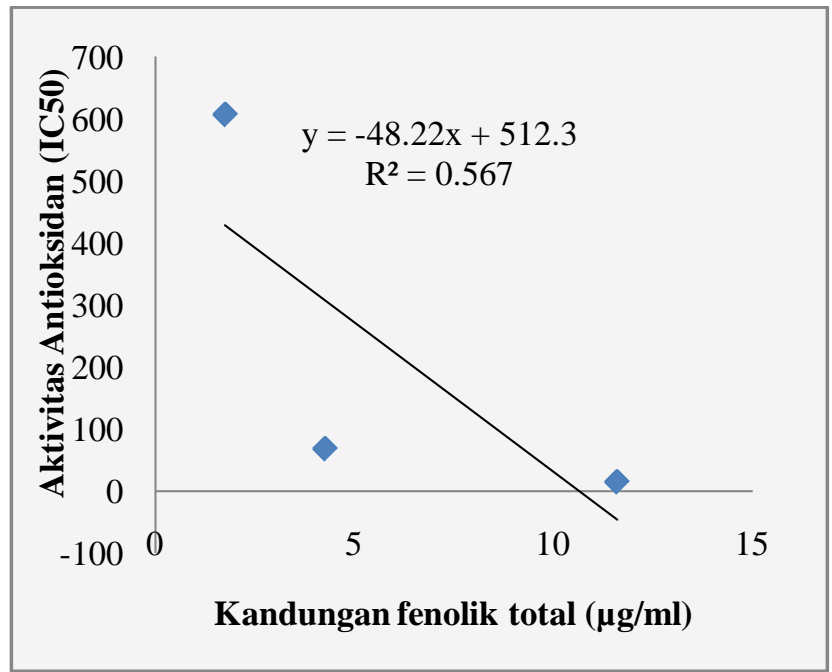

(a)

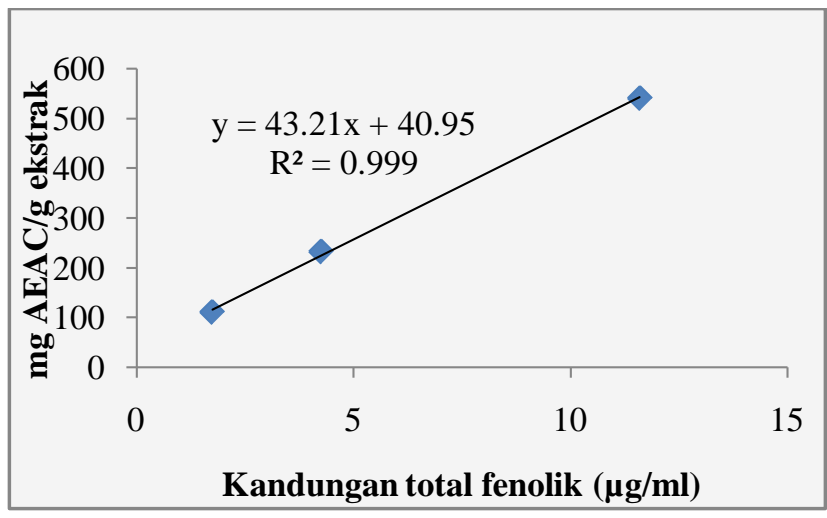

(b)

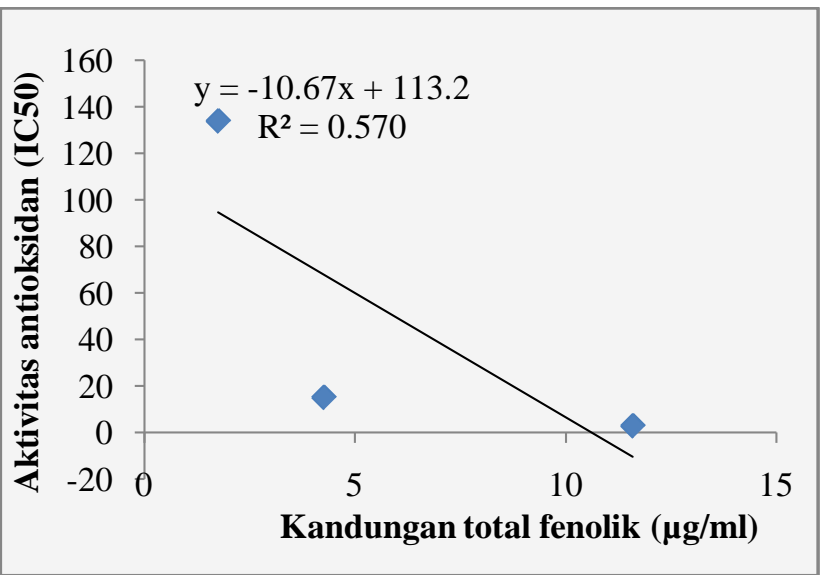

(c)

Gambar 1. Kurva korelasi antara kandungan total fenolik terhadap aktivitas dalam meredam radikal (a) DPPH, (b) FRAP, dan (c) ABTS 


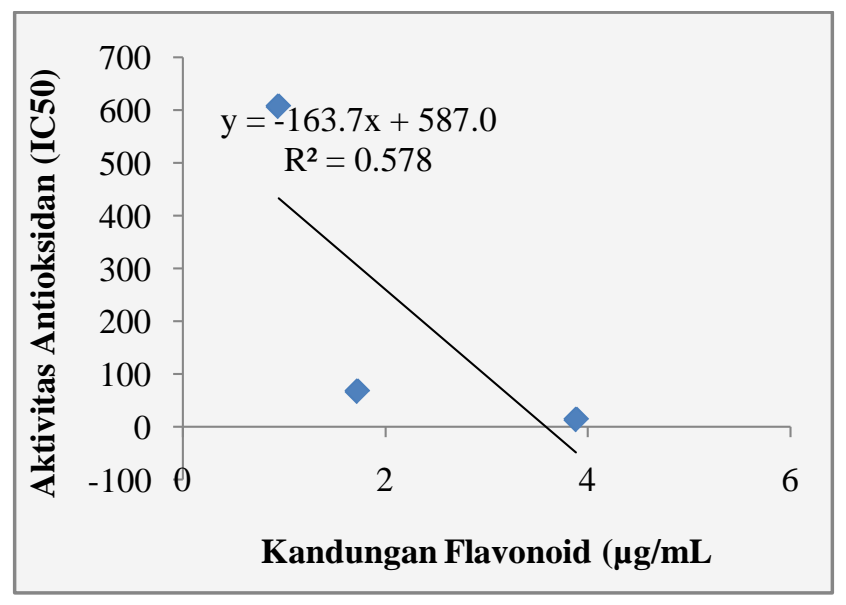

(a)

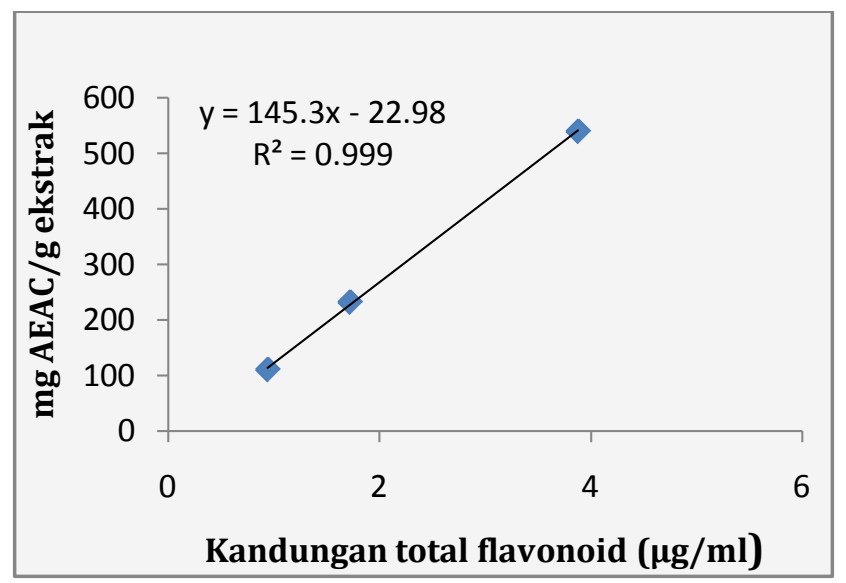

(b)

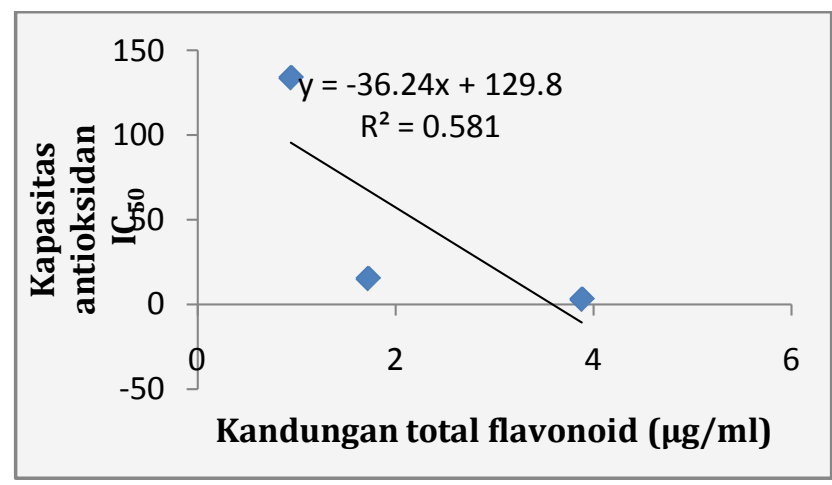

(c)

Gambar 2. Kurva korelasi antara kandungan total flavonoid terhadap aktivitas dalam meredam radikal (a) DPPH, (b) FRAP, dan (c) ABTS

Sedangkan untuk pengujian peredaman radikal kation ABTS diperoleh hubungan antara kandungan total flavonoid dan fenolik terhadap aktivitas antioksidan dalam meredam radikal kation ABTS dengan nilai koefisien korelasi berturt-turut sebesar 0,581 dan 0,570 (Gambar 1c dan 2c) yang berarti bahwa total flavonoid dan fenolik memberikan kontribusi sebesar $58,1 \%$ dan $57,0 \%$ dalam aktivitasnya sebagai antioksidan sedangkan selebihnya dipengaruhi oleh senyawa lainnya.

Menurut (Sandrasari, 2009, Apak et al., 2007), senyawa fenolik berupa flavonoid yaitu flavonol dan flavon dapat berperan sebagai antioksidan. Aktivitas flavonoid sangat bergantung terhadap jumlah dan lokasi gugus - $\mathrm{OH}$ dimana dalam hal ini berperan dalam menetralkan radikal bebas. Kemampuan flavonoid dalam menekan radikal bebas pun berkaitan dengan kemampuanya mendonorkan elektron. Hal inilah yang menyebabkan hubungan antara kandungan total fenol dengan aktivitas antioksidan. Semakin tinggi nilai total fenol dan flavonoid maka semakin tinggi kemampuan antioksidan dalam mendonorkan elektronnya dalam hal menekan perkembangan radikal bebas. Komponen fenolik ataupun flavonoid merupakan senyawa utama dalam peranan antioksidan (Al-Farsi et al., 2007).

\section{KESIMPULAN}

Berdasarkan hasil penelitian maka dapat disimpulkan bahwa kadar total flavonoid dan fenolik pada daun jati putih diperoleh kadar yang tertinggi pada fraksi etil asetat (EA) dan aktivitas antioksidan juga menunjukkan bahwa fraksi EA memberikan aktivitas yang sangat kuat baik pada pengujian DPPH, ABTS maupun FRAP. Sedangkan korelasi antara kadar total flavonoid dan fenolik dari ekstrak dan fraksi terhadap aktivitas dalam meredam radikal DPPH dan ABTS diperoleh korelasi sedang sedangkan hubungan terhadap daya reduksi besi pada pengujian FRAP diperoleh korelasi yang tinggi.

\section{UCAPAN TERIMA KASIH}

Ucapan terima kasih disampaikan kepada Institusi Akademi Farmasi Kebangsaan dan Sekolah Tinggi Ilmu Farmasi Makassar yang telah memberikan fasilitas dalam penelitian.

\section{DAFTAR PUSTAKA}

Adhyapak, S., Dighe, V., Mestry, D. \& Shambhu, N. (2011). High performance liquid chromatographic method for quantization of apigenin from dried root powder of Gmelina 
arborea Linn. World Journal of Science and Technology, 2, 742-749.

Al-Farsi, M., Alasalvar, C., Al-Abid, M., Al-Shoaily, K., Al-Amry, M. \& Al-Rawahy, F. (2007). Compositional and functional characteristics of dates, syrups, and their by-products. Food Chemistry, 104, 943-947.

Amzad Hossain, M. \& Shah, M. D. (2015). A study on the total phenols content and antioxidant activity of essential oil and different solvent extracts of endemic plant Merremia borneensis. Arabian Journal of Chemistry, 8, 66-71.

Apak, R., Güçlü, K., Demirata, B., Özyürek, M., Çelik, S., Bektaşoğlu, B., Berker, K. \& Özyurt, D. (2007). Comparative Evaluation of Various Total Antioxidant Capacity Assays Applied to Phenolic Compounds with the CUPRAC Assay. Molecules, 12, 1496.

Benzie, I. F. F. \& Strain, J. J. (1996). The Ferric Reducing Ability of Plasma (FRAP) as a Measure of "Antioxidant Power": The FRAP Assay. Analytical Biochemistry, 239, 70-76.

Chothani, D. L. \& Patel, N. M. (2012). Preliminary phytochemical screening, pharmacognostic and physicochemical evalution of leaf of Gmelina arborea. Asian Pacific Journal of Tropical Biomedicine, 2, S1333-S1337.

Chun, O. K., Kim, D. O. \& Lee, C. Y. (2003). Superoxide radical scavenging activity of the major polyphenols in fresh plums. J Agric Food Chem, 51, 8067-72.

Cos, P., Ying, L., Calomme, M., Hu, J. P., Cimanga, K., Van Poel, B., Pieters, L., Vlietinck, A. J. \& Vanden Berghe, D. (1998). Structure-activity relationship and classification of flavonoids as inhibitors of xanthine oxidase and superoxide scavengers. J Nat Prod, 61, 71-6.

Harborne, J. B. (1987). Metode fitokimia : penuntun cara modern menganalisis tumbuhan / J.B. Harborne; penerjemah Kosasih Padmawinata, Iwang Soediro; penyunting Sofia Niksolihin, Bandung, ITB.

Iqbal, E., Salim, K. A. \& Lim, L. B. L. (2015). Phytochemical screening, total phenolics and antioxidant activities of bark and leaf extracts of Goniothalamus velutinus (Airy Shaw) from Brunei Darussalam. Journal of King Saud University - Science, 27, 224-232.

Joshi, N., Bhatt, S., Suresh Dhyani, D. \& Nain, J. (2013). Phytochemical screening of secondary metabolites of Argemone mexicana Linn. Flowers. International Journal of Current Pharmaceutical Research 5, 144-147.

Karadeniz, F., Burdurlu, H. S., Koca, N. \& Soyer, Y. (2005). Antioxidant activity of selected fruits and vegetables grown in Turkey. Turk $J$ Agric For, 29, 297-303.

Kaur, N., Kaur, S., Bedi, P. \& Kaur, R. (2012). Preliminary pharmacognostic study of Gmelina arborea bark. Int J Nat Prod Sci, 1, 184.

Konaté, K., Souza, A., Roland, M., Coulibaly, A., Kiendrebeogo, M., Lamien-Meda, A., Lamidi, M., Millogo-Rasolodimby, J. \& Nacoulma, O. G. (2010). Polyphenol contents, antioxidant and anti-inflammatory activities of six Malvaceae species traditionally used to treat hepatitis B in Burkina Faso. European Journal of Scientific Research, 44, 570-580.

Kulisic, T., Radonic, A., Katalinic, V. \& Milos, M. (2004). Use of different methods for testing antioxidative activity of oregano essential oil. Food Chemistry, 85, 633-640.

Kurniasih, N., Kusmiyati, M., Sari, R. P. \& Wafdan, R. (2015). Potensi Daun Sirsak (Annona muricata Linn), Daun Binahong (Anredera cordifolia (Ten) Steenis), Dan Daun Benalu Mangga (Dendrophthoe pentandra) Sebagai Antioksidan Pencegah Kanker. Jurnal ISTEK, 9, 162-183.

Kusumowati, I. T. D. (2012). Korelasi Kandungan Fenolik Dan Aktivitas Antiradikal Ekstrak Etanol Daun Empat Tanaman Obat Indonesia (Piper bettle, Sauropus androgynus, Averrhoa bilimbi, dan Guazuma ulmifolia). Pharmaceutical Journal of Indonesia, 13, 5.

Lü, J.-M., Lin, P. H., Yao, Q. \& Chen, C. (2010). Chemical and molecular mechanisms of antioxidants: experimental approaches and model systems. Journal of Cellular and Molecular Medicine, 14, 840-860. 
Madhan Shankar, S. R., Rajendraprasad, G., Karthik, N., Rajendran, R. \& V S, M. (2009). Allelopathic effects of phenolics and terpenoids extracted from Gmelina arborea on germination of Black gram (Vigna mungo) and Green gram (Vigna radiata). Allelopathy Journal, 23, 323-332.

Middleton, E., Jr., Kandaswami, C. \& Theoharides, T. C. (2000). The effects of plant flavonoids on mammalian cells: implications for inflammation, heart disease, and cancer. Pharmacol Rev, 52, 673-751.

Molyneux, P. (2003). The use of the stable radical Diphenylpicrylhydrazyl (DPPH) for estimating antioxidant activity.

Nur, S., Rumiyati, R. \& Lukitaningsih, E. (2017). Screening Of Antioxidants, Anti-Aging And Tyrosinase Inhibitory Activities Of Ethanolic And Ethyl Acetate Extracts Of Fruit Flesh And Fruit Peel Langsat (Lansium domesticum Corr) In Vitro. Trad. Med. J, 22, 63 - 72.

Robinson, T. (1995). Kandungan organik tumbuhan tinggi / Trevor Robinson ; penerjemah Kosasih Padmawinata ; penyunting Tetet Sutomo, Bandung, ITB.

Sandrasari, D. A. (2009). Kapasitas Antioksidan dan Hubungannya dengan Nilai Total Fenol Ekstrak Sayuran Indigenous. Thesis, Institute Pertanian Bogor.

Shahwar, D., Rehman, S. U., Ahmad, N., Ullah, S. \& Raza, M. (2010). Antioxidant activities of the selected plants from the family Euphorbiaceae, Lauraceae, Malvaceae and Balsaminaceae. African Journal of Biotechnology, 9, 10861096.

Tahir, I., Wijaya, K., Kimi, P., Jogjakarta, U. G. M. \& Bambang, P. (2003). Terapan Analisis Hansch untuk Aktivitas Antioksidan Senyawa Turunan Flavon / Flavonol. In: UGM (ed.) Makalah Seminar Khemometri. Jurusan Kimia FMIPA UGM Yogyakarta.

Vijay, T., Rajan, M. S. D., Sarumathy, K., Subramani, P. \& Sakthivel, K. (2011). Cardioprotective, antioxidant activities and phytochemical analysis by GC-MS of gmelina arborea (GA) in doxorubicin-induced myocardial necrosis in albino rats. Journal of Applied Pharmaceutical Science, 01, 198-204.

Wang, C. C., Chu, C. Y., Chu, K. O., Choy, K. W., Khaw, K. S., Rogers, M. S. \& Pang, C. P. (2004). Trolox-equivalent antioxidant capacity assay versus oxygen radical absorbance capacity assay in plasma. Clin Chem, 50, 952954. 